\title{
A VÁLLALATOK TÁRSADALMI FELELÓSSÉGVÁLLALÁSÁNAK FOGYASZTÓI MEGÍTÉLÉSE
}

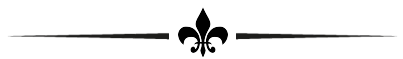

\section{CONSUMER PERCEPTION OF CORPORATE SOCIAL RESPONSIBILITY}

\author{
- \\ ${ }^{1}$ KovÁCS, Ildikó \\ ${ }^{1}$ LEHOTA, József \\ ${ }^{2}$ KomÁROMI, Nándor

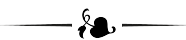 \\ ${ }^{1}$ Szent István Egyetem, Gazdaság- és Társadalomtudományi Kar, Gazdálkodás és Szervezéstudományok Doktori Iskola \\ (Szent István University, Doctoral School of Management and Business Administration) \\ H-210o Gödöllő, Páter Károly út 1. \\ 22Szent István Egyetem, Gazdaság- és Társadalomtudományi Kar, Üzleti Tudományok Intézet \\ (Szent István University, Faculty of Economics and Social Sciences, Business Studies Institute) \\ H-2100 Gödöllő, Páter Károly út 1. \\ e-mail: valko.kovacs.ildiko@gmail.com
}

a

Several studies have drawn attention to the importance of and the impact on consumer behavior of the corporate efforts in order to promote sustainable consumption in the last decades. The concept and framework of sustainable consumption appear at global, European and national levels. Several studies have examined the possible design and modeling opportunities for sustainable societies. The socially responsible operation of companies and their efforts for sustainable consumption can be the driving force behind social changes. In our study, we examined the consumer's perception of social responsibility of companies on based on a national representative sample of 1,038 respondents over 15 years of age. In our analysis, opinions and attitudes related to sustainable development are presented, followed by the characterization of the groups that can be separated on the basis of the monitoring of sustainable corporate activities. The research shows that only a minority the consumers do not believe that consumers could make to sustainable development through their decisions. In contrast, nearly a third of domestic consumers is neutral or attaches importance to the efforts of companies for sustainable development, which is average by European standards. The company moves which lead to better opinions of domestic consumers, or which may lead to the rejection of shopping are introduced. Four groups of consumers are separated according to the monitoring of sustainable business activities.

KULCSSZAVAK: társadalmilag tudatos fogyasztás, vállalatok társadalmi felelősségvállalása, fenntartható fogyasztás, ,jó ügyért" vásárlás, bojkott, fogyasztói magatartás
KEYWORDS: socially responsible consumption, corporate social responsibility, sustainable consumption, buycott, boycott, consumer behavior

\section{BEVEZETÉS - INTRODUCTION}

Az utóbbi évek tanulmányai bizonyítják a társadalmilag tudatos fogyasztói attitűdök erősödését, és egyre bővülnek azok a fogyasztói csoportok, amelyek a felelős fogyasztói magatartás egyes megjelenési formáival jellemezhetők. A vállalatok társadalmi felelősségvállalása amely a fejlett országokban a hetvenes évektől folyamatosan terjedt el - összefüggésbe hozha- tó a társadalmilag tudatos fogyasztás terjedésével, és a marketing szerepének megítélésében is változást hozott. SMITH (2008) cikkén alapulva - melynek központi gondolata, hogy meghatározza a vállalati felelősségvállalás korlátait - az Üzleti Fenntarthatósági Hálózat (Network for Business Sustainability - NBS) 2010-ben dolgozta ki a vállalati társadalmi felelősségvállalás hatásait a marketing elvei mentén vizsgáló „A CSR marketing hatásai és 
korlátai” című tanulmányát. Ebben vizsgálta az egyes vállalati lépések hatásait, amelyeken keresztül lehetőség nyílik egyes társadalmi problémákra hatékony válaszokat adni. Eredményeiket négy terület köré csoportosították: (1) a vállalatok tevékenységének társadalmi hatásai, kevésbé káros termékek gyártása, (2) a vállalati tevékenységek indirekt társadalmi hatásai, mint például kevéssé környezetszennyező, vagy méltányos kereskedelemból származó termékek forgalmazása, (3) a CSR visszaszorítása a túlságosan költséges társadalmi szerepvállalás esetén, ha az veszélyezteti a gazdasági túlélési lehetőséget, (4) a fogyasztói normáknak és elvárásoknak való megfelelés.

Ez utóbbi kérdés körüljárásával kutatásunk fó célja az volt, hogy részletesen elemezzünk a vállalati társadalmi felelősségvállalás iránti fogyasztói attitűdöket és általános ismereteket, valamint jellemezzünk olyan fogyasztói csoportokat, amelyek fogékonyak a vállalatok fenntartható fogyasztást szolgalmazó kommunikációjára.

\subsection{A társadalmilag felelős fogyasztás megjelenési formái - Forms of Socially Responsible Consumption}

A társadalmilag felelős fogyasztás már évszázadokkal ezelőtt ismert és elfogadott volt (CRANE, 2001), a tudományos érdeklődés homlokterébe viszont csak a 70-es évektől került, kutatása igazi lendületet a fenntartható fogyasztás eszméjének terjedésével kapott. Az utóbbi évek hazai felmérései is hangsúlyozzák, hogy egyre inkább elterjed az etikus és környezettudatos értékek figyelembe vétele a fogyasztói döntések során, amely hozzáadott értéket jelent a termék alapvető jellemzői mellett.

A társadalmilag tudatos fogyasztás fogalmát használó első szakirodalmi forrás az Anderson és Cunningham 1972-es kutatását bemutató cikk, amelyben BERKOWITZ és LUTTERMAN (1968) skáláját használva társadalmilag tudatos fogyasztói csoportokat mutattak ki. Elsőként WEBSTER (1975) munkájában jelent meg a társadalmilag felelős fogyasztó definíciója, mely szerint a társadalmilag felelős fogyasztó figyelembe veszi egyéni fogyasztása társadalmi következményeit, vagy figyelmet fordít arra, hogy vásárlóereje révén visszafor- dítsa a társadalomban bekövetkező változásokat. Ez a meghatározás alapozta meg a későbbi kutatásokat, amelyek a társadalmi felelősség fogyasztói döntéshozatalban való megjelenését vizsgálták.

A társadalmilag felelős fogyasztás fogyasztói megkérdezésen alapuló vizsgálata a nemzetközi és a hazai publikációkban is elhanyagolt területnek számít, mindössze néhány kutatás lelhető fel. Egyes részterületeken azonban mint például a környezettudatos fogyasztás, illetve a helyi termékek vásárlásával kapcsolatos felmérések - bő szakirodalom jelenik meg és hazai kutatási eredmények is hozzáférhetőek. Fogyasztói megkérdezésen keresztül a társadalmilag felelős fogyasztás cselekvési formáit vizsgálta COOPER-MARTIN és HOLBROOK (1993), kutatásukban fogyasztókat kértek etikus fogyasztói magatartásformák és ügyek felsorolására, majd erre alapozva kijelölték az etikus fogyasztói magatartásra jellemző megjelenési formákat:

- nem-fogyasztás: célja a fogyasztás környezeti, illetve társadalmi hatásainak mérséklése,

- értékelvű hétköznapi vásárlás: a környezetileg, illetve társadalmilag elfogadhatóbb alternatívák kiválasztása,

- bojkott: kiváltó oka legtöbb esetben egy vállalat vagy egy állam tevékenységével való elégedetlenség,

- pozitív bojkott (buycott): egy aktuális ügy támogatása miatt választanak bizonyos terméket,

- óvatos, megóvó használat: a takarékosságot, újrahasznosítást, megóvást, felújítást értjük alatta,

- használat utáni elhelyezés, ártalmatlanítás: szelektív gyuujjtés.

Felmérésükből kiindulva később több nemzetközi kutatás is született, amely igazolta a vállalatok társadalmi felelősségvállalásának etikus fogyasztói döntésekben való megjelenését. CRANE (2001) kutatásában a termékbiztonság, a környezeti hatások, a fogyasztói adatvédelem, a munkavállalói jólét biztosítása, a méltányos árazás, vállalati adományozás jelenik meg. FRANÇOIS-LECOMPTE és ROBERTS (2006) munkájában a vállalat magatartása (a nem felelős vállalatok termékeinek elutasítása), a jó ügyhöz kötött termékek vásár- 
lása (a bevétel egy része előre ismert ügyet szolgál), a kis üzletek segítése (törekvés arra, hogy a szupermarketek helyett a kis üzletek fennmaradását segítsék elő), a termékek földrajzi eredetének figyelembe vétele, valamint a fogyasztás mértékének csökkentése (túlfogyasztás visszafogása) szerepel. WEBB, MOHR és HARRIS (2008) a cégek CSR teljesítményének befolyását a fogyasztói vásárlásokra, a fogyasztói recycling magatartást és a termékek környezeti hatásán alapuló vásárlási kritériumokat említi.

FRANÇOIS-LECOMPTE és ROBERTS (2006) megfogalmazásában a társadalmilag felelős fogyasztás olyan termékek vásárlását és szolgáltatások igénybevételét jelenti, amelyek pozitív vagy nem negatív hatással vannak a fizikai környezetre és/vagy a fogyasztó arra használja vásárlóerejét, hogy társadalmi ügyeket mozdíthasson előre. Ez a definíció összhangban van a vállalatok társadalmi felelősségvállalásának koncepciójával. Eszerint a társadalmilag tudatos fogyasztó figyelembe veszi az érintettek jóllétét is, amely hatást vásárlásain keresztül éri el.

A vállalatok társadalmi felelősségvállalását tekintve a nemzetközi szakirodalomban jól kirajzolódik annak fogyasztói magatartásra való hatása. A társadalmilag felelős fogyasztás cselekvési formáinak vizsgálatában - amelyen belül megjelenik a vállalatok társadalmi felelősségvállalásának fogyasztói döntésekben való megjelenése is - hazai kutatási eredmények is rendelkezésre állnak. KOVÁCS (2015) felmérése alapján kimutathatókká váltak fogyasztói csoportok, amelyek figyelembe vesznek olyan vállalati magatartási formákat is, amelyeknek lényeges jellemzője a társadalmi hatások figyelembe vétele. A hazai, társadalmilag felelős fogyasztói csoportok elkülönítésére alkalmas jellemzőcsoportok, amelyek alapján a hazai etikus fogyasztás jellegzetességei leírhatók: a szociális szempontok, a környezeti szempontok, a hulladékcsökkentés, a termékjellemzők és a helyi vásárlás. A kutatás eredményei szerint vállalati felelősségvállalás négy jellemzőcsoportja mutatható ki, amely alkalmasnak bizonyult a társadalmilag felelős fogyasztói klaszterek elkülönítésére: a társadalmi segítségnyújtás, a környezet védelme, munkavállalók és vevők (vevőpanaszok kezelése). Az etikus terméktu- lajdonságok hangsúlyosabbá válását a fenntartható értékrendet követő fogyasztói csoportok vizsgálatai (LEHOTA, HORVÁTH és RÁCZ, 2013; SZAKÁLY et al., 2015) is igazolták.

A vállalatok társadalmi felelősségvállalásának etikus fogyasztói döntésekben való megjelenését nemzetközi és hazai eredmények is igazolják, amely a fogyasztói normáknak és elvárásoknak való megfelelésen keresztül hatással kell, hogy legyenek a vállalatok társadalmi szerepvállalására.

\subsection{A vállalatok társadalmi felelősség- vállalásának fogyasztói megítélése - Consumer Perceptions of Corporate Social Responsibility}

A vállalatok társadalmi felelősségvállalásának programjai elősegíthetik a korábbi fogyasztási minták megváltoztatását, és afelé irányíthatják fogyasztóikat, hogy olyan termékeket válasszanak, amelyek kisebb társadalmi terheléssel járnak, vagy társadalmi szempontból előnyösek, esetleg csökkentsék fogyasztásukat.

2014-ben a Nielsen piackutató vállalat által végzett „Társadalmi felelősségvállalás és fogyasztói döntés” globális omnibusz kutatása során 56 országban - köztük Magyarországon - több mint 25 ezer fogyasztót kérdeztek meg. A kutatás megállapításai szerint Magyarországon egyre több fogyasztó hajlandó többet fizetni egy termékért vagy szolgáltatásért, ha tudja, hogy az érintett vállalat közvetlenül támogat társadalmi célokat. A megkérdezett hazai fogyasztók kétharmada szívesebben vásárol árucikket vagy szolgáltatást olyan vállalatoktól, amelyek programjában szerepel a társadalmi felelősségvállalás, míg az európai átlag 55\%, tehát az európai átlag felett díjazzák a magyar fogyasztók a vállalatok társadalmi felelősségvállalását. Minden második magyar fogyasztó kész többet fizetni egy áruért, ha tudja, hogy gyártója közvetlenül támogat társadalmi törekvéseket. Emellett pedig szívesebben dolgozik pozitív társadalmi és környezetvédelmi hatások iránt elkötelezett cégnél a hazai megkérdezettek 67, míg az európai átlag 53\%-a.

Több hazai tanulmány is készült a vállalatok társadalmi felelősségvállalásának ismeretére és elfogadottságára vonatkozóan. A Tudatos Vásárlók Egyesülete - TVE (2005) szerint 
a magyar fogyasztók közel fele, 47\%-a úgy véli, hogy vásárlói döntésével képes befolyásolni a vállalatokat: ha a fogyasztók előnyben részesítenék a társadalmi felelősséget vállaló és környezetbarát módon múködő vállalatok termékeit, a vállalatok igyekeznének megfelelni ezeknek az elvárásoknak. KOVÁCS (2015) eredményei alapján megállapíthatóvá vált, hogy a fogyasztók nagy része (61\%) bízik fogyasztása társadalmi hatásaiban, és amennyiben nem, annak oka nem a szkeptikusság, hanem inkább a megfelelő informáltság hiánya.

A TVE (2010) és KOVÁCS (2015) kutatása is visszaigazolja több vállalati tevékenység figyelembe vételét a fogyasztói döntésekben, amelyek átlagos fontossága minden vizsgált jellemzőnél emelkedést mutat. Mindkét felmérés szerint legtöbben az alkalmazottakkal való bánásmódot tartják fontosnak, ez után következik a helyi közösségek támogatása, amelyek mellett a lokálpatrióta szempontok is kiemelkedőek. A kutatások kiemelték még a hátrányos helyzetűek alkalmazását, a jótékony, karitatív célokra való adományozást, a helyi közösségek fejlesztésének támogatását, amelyek átlagos fontossága kiemelkedő. A két felmérés eredményeinek összehasonlítása rávilágít arra, hogy a vizsgált jellemzők mindegyike esetén emelkedett a fontosnak vagy nagyon fontosnak tartó válaszadók aránya és az átlagos fontosság mértéke is. A korábbi felmérésben a Magyarországon való termelés bizonyult a legfontosabbnak, amelyet másodikként a hátrányos helyzetűek alkalmazása követett, az utóbbi felmérés szerint ezeket a jellemzőket megelőzi, hogy a vállalat átlagon felül is jól bánjon alkalmazottaival és támogassa a helyi közösségek fejlesztését.

A vállalatokról szóló negatív információk megítélése közül GULYÁS (2008) és KOVÁCS (2015) felmérései alapján a fogyasztók megtévesztése és a környezetszennyezés emelkednek ki, amelyet mindkét kutatás igazolt. Kiemelkedő szempontok ezek mellett fontossági sorrendben a megalázó munkakörülmények, a kozmetikai célú állatkísérletek alkalmazása, adók be nem fizetése. A felsorolt jellemzőknél a potenciális bojkottálók aránya 25,3-46,2\%, azok aránya pedig akik akkor is áttérnének más vállalat termékére, ha az drágább 39,8-52,0\%. A későbbi (KOVÁCS, 2015) eredményekből jól látszik, hogy a kozmetikai célú állatkísérletek alkalmazása, az adók be nem fizetése, valamint a helyi közösségek fejlesztésének támogatása azok a jellemzők, amelyeknek fontossága legnagyobb mértékben emelkedett az elmúlt években.

A pozitív megkülönböztetés legfontosabb okai KOVÁCS (2015) alapján pedig: az etikus múködés, a munkakörülmények javításának fontossága, valamint a hátrányos helyzetưek vagy más munkaképességúek alkalmazása. Emellett a helyi közösségek fejlesztését, a munkavállalói elégedettség figyelembe vételét is a válaszadók közel $80 \%$-a ítéli fontosnak. GULYÁS (2008) megállapításai alapján a hazai fogyasztók hajlandóak többet fizetni olyan termékért, amely magyar termék vagy gyártójának tulajdonosai magyarok, emellett ha a termék vásárlásával jótékony, karitatív tevékenységét is támogathatnak, vagy ha a vállalat hátrányos helyzetűek alkalmazását (más munkaképességüek), illetve a helyi közösségek fejlesztését segíti.

A bemutatott hazai kutatások eredményei bizonyítják a társadalmilag felelős vállalatok termékeinek keresését az etikus fogyasztók körében. NEILSON (2010) kutatása azonban felhívja a figyelmet a bojkottokban és a pozitív megkülönböztetésben (buykottokban) résztvevők különbözőségére, amelyet jelen kutatásunkban is vizsgálunk.

\section{ANYAg ÉS MóDSzer - MATERIAL AND METHOD}

A kutatás célkitűzéseinek megvalósítása érdekében 2013-ban országos kérdőíves felmérésre került sor, 103815 év feletti válaszadó bevonásával. Mintavételi módszerként a véletlen séta elvét alkalmaztuk, amely teljes véletlenszerűséget biztosít a megfelelő válaszadók kiválasztásához. Végezetül a reprezentativitás biztosítása érdekében a mintát többdimenziós súlyozással a nem és a lakóhely településtípusa jellemzőkre korrigáltuk, így a minta ezek alapján tükrözi az alapsokaság (a 15 év feletti hazai fogyasztók) összetételét.

A kérdőív kérdéscsoportokat tartalmazott a fenntartható fejlődéssel kapcsolatos véleményekről, a vállalatok fenntartható fejlődés érdekében tett lépéseinek megítéléséről, ame- 
lyek kapcsán jobb vélemény alakulhat ki egy vállalattal kapcsolatban, illetve hogy a hazai fogyasztók nyomon követik-e, hogy a rendszeresen vásárolt termékek gyártói mit tesznek a fenntartható fejlődés érdekében. Ezen kérdéscsoportok alapján elkülöníthető fogyasztói csoportok váltak kimutathatóvá. A fenntartható fogyasztás fontosságát és a vállalatok részvételét a fenntartható fogyasztás elterjedésében, valamint ezek fogyasztói megítélését közvetlen kérdésekkel is vizsgáltuk. A kérdőívek feldolgozását matematikai-statisztikai program segítségével (SPSS 16.0) végeztük. A százalékos megoszlások esetében Chi-négyzet, illetve Cramer-féle V próbával szignifikancia elemzéseket, a fogyasztói csoportok kialakításához klaszterelemzést alkalmaztunk.

\section{EREDMÉNYEK - RESUlts}

Kutatásunk eredményeit két fejezetrészre bontva mutatjuk be. Elsőként kerül sor a fogyasztás fenntartható fejlődésre való hatásával kapcsolatos általános vélemények és a vállalatok társadalmi felelősségvállalásával kapcsolatos attitűdök bemutatására. Második részben pedig a fenntartható vállalati tevékenységek figyelemmel kísérése alapján elkülöníthető csoportok jellemzőit mutatjuk be.

\subsection{A fogyasztás fenntartható fejlődésre gyakorolt hatásainak értékelése - Evaluation of the Impact of Consumption on Sustainable Development}

Kutatásunk során elsőként a fogyasztás, fenntartható fejlődésre való hatásának megítélését, illetve azt vizsgáltuk, hogy melyek azok az erőfeszítések, amelyeket a hazai fogyasztók a fenntartható fogyasztás érdekében tesznek.

A kapott válaszokat elemezve megállapítható, hogy a hazai fogyasztók többsége nem bízik abban, hogy vásárlási döntésein keresztül képes lenne hatást gyakorolni a fenntartható fejlődésre. A válaszadók 39\%-a személyesen is megtesz minden tőle telhetőt, ezen belül pedig 12\%-uk környezetét is igyekszik befolyásolni és hasonló hozzáállásra buzdítani. Csupán a fogyasztók 18\%-a az, aki nem hisz abban, hogy bármit is tudna tenni a fenntartható fejlődés érdekében és ezért nem is foglalkozik vele. Vizsgálva a fenntarthatóság érdekében tett erőfeszítéseket arra voltunk kíváncsiak, hogy melyek azok, amelyeket a jövőben biztosan megtennének a hazai fogyasztók. Eredményeinket az 1. táblázatban mutatjuk be.

A fenntarthatóság érdekében tett erőfeszítések sorrendje alapján leginkább elterjedt az energiatakarékosságra való törekvés több formája, valamint az újrahasznosítás, emellett jelenik meg a helyi előállítású / termesztésű termékek előnyben részesítése és a környezetbarát termékek vásárlása. Szintén nagy elfogadottságot mutat a munkába járáshoz tömegközlekedés igénybevétele vagy a kerékpárhasználat. A bio élelmiszerek előnyben részesítése, illetve az állati eredetú élelmiszerek fogyasztásának viszszafogása, valamint az önkéntes munkavégzés már csak a válaszadók kisebb hányadára igaz.

A leginkább fontosnak tartott vállalati erőfeszítések a környezetkárosító tevékenység(ek) csökkentése és az egészségügy támogatása, amelyet a hátrányos helyzetúek támogatása, a környezetvédelmi beruházások finanszírozása és az energiatakarékos megoldások alkalmazása követ. Korábbi hazai kutatások eredményei (GULYÁS, 2008; KOVÁCS, 2015) hasonlóképp a környezet iránti elkötelezettséget mutatták ki legfontosabb jellemzőként. Felmérésünk szerint a rendszeresen vásárolt termékek gyártóinak fenntartható fejlődés érdekében tett erőfeszítéseit a hazai fogyasztók közel fele figyeli. Az erre irányuló információkat a válaszadók 5,4\%-a rendszeresen, 43,8\%-a pedig csak néha követi nyomon. A válaszadók fele (50,8\%-a) vallotta úgy, hogy soha sem figyel erre a szempontra vásárlásai során.

A pozitív megítélést segítő vállalati lépések mellett vizsgálataink kitértek arra is, hogy mely esetben utasíthatják el a fogyasztók a további vásárlást, azaz, ha egy rendszeresen vásárolt termék gyártójáról negatív híreket olvasnak, az milyen hatással lehet a további vásárlásokra. Eredményeink arra utalnak, hogy a fogyasztók kisebb hányada változtatna ilyen információk hatására korábbi szokásain. „Nem vásárolom tovább a termékeit” választ a megkérdezettek csupán 9,7\%-a adott, „Ha tehetem és van más megbízható gyártó, inkább annak a termékeit vásárolom" választ 28,1\%-ban adták. 37,8\% elgondolkodik rajta, hogy a jövőben vásárolja-e 
termékeit, és 24,4\%-ának pedig nem befolyásolják vásárlási döntéseit. A vállalatokkal kapcsolatos negatív hírek közül azokat, amelyek a hazai fogyasztókat megfontolásra intenék egy gyártó termékeinek vásárlásával kapcsolatban a 2. táblázat mutatja az ,igen” válaszok csökkenő sorrendjében.

Az eredményekból jól látszik az emberre veszélyes alapanyagok használatának kiemelkedő értéke, amely esetben 70,1\% utasítaná el a további vásárlást. A következő lényeges szempont, a felhasznált alapanyagok kétes eredete miatt pedig már csak 55,6\%. Ezután következik - a korábban ismertetett két kutatás
(TVE, 2005; KOVÁCS，2015） eredményeihez hasonlóan - a környezetszennyezés és az állatkísérletek alkalmazása, amely esetén a válaszadók közel fele utasítaná el a vásárlást. A jelen felmérés két legfontosabbnak ítélt jellemzője a korábbi kutatásokban nem szerepelt. Összegezve megállapítható, hogy a hazai fogyasztók fenntarthatósághoz való fogyasztáson keresztüli hozzájárulásukat illetően kevésbé bizakodóak, és leginkább a környezetterhelés csökkentését tartják szem előtt mind saját erőfeszítéseiket, mind pedig a vállalatokkal szembeni elvárásaikat illetően.

A fenntarthatóság érdekében tett személyes erófeszítések (Personal Efforts for Sustainability)

\begin{tabular}{|c|c|c|}
\hline $\begin{array}{l}\text { Válaszlehetôségek } \\
\text { (Answers) }\end{array}$ & $\begin{array}{c}\text { Fö } \\
\text { (Head) }\end{array}$ & $\begin{array}{c}\text { Az igen válaszok } \\
\text { megoszlása } \\
\text { (Distribution of } \\
\text { Answers ,Yes”) } \\
\text { (\%) }\end{array}$ \\
\hline $\begin{array}{l}\text { Lekapcsolok minden szükségtelen világítást és nem hagyom készenléti } \\
\text { üzemmódban a készülékeket (I switch off all unnecessary lights and do } \\
\text { not leave appliances on standby) }\end{array}$ & 947 & 91,2 \\
\hline $\begin{array}{l}\text { Hagyományos izzók energiatakarékosra történő cseréje (Replacement of } \\
\text { traditional light bulbs with energy-saving light sources) }\end{array}$ & 803 & 77,4 \\
\hline $\begin{array}{l}\text { Előnyben részesítem a helyi előállítású / termesztésű termékeket } \\
\text { (I prefer the locally produced / grown products) }\end{array}$ & 740 & 71,3 \\
\hline $\begin{array}{l}\text { Munkába járáshoz tömegközlekedést veszek igénybe vagy kerékpározok } \\
\text { (I get to work using public transport or biking) }\end{array}$ & 649 & 62,5 \\
\hline Újrahasznosítok, ahol van rá mód (I recycle if there's a way) & 630 & 60,7 \\
\hline Környezetbarát termékeket vásárolok (I buy Eco-friendly products) & 602 & 58,0 \\
\hline Falak hőszigetelése (Thermal insulation of walls) & 379 & 36,5 \\
\hline Előnyben részesítem a bio élelmiszereket (I prefer organic foods) & 312 & 30,1 \\
\hline $\begin{array}{l}\text { Kevesebb állati eredetű élelmiszert fogyasztok (I consume less food of } \\
\text { animal origin) }\end{array}$ & 263 & 25,3 \\
\hline $\begin{array}{l}\text { Önkéntes munkát végzek egy civil szervezet számára (I perform volunta- } \\
\text { ry work in a non-governmental organization) }\end{array}$ & 140 & 13,5 \\
\hline Egyik sem (None of them) & 15 & 1,4 \\
\hline
\end{tabular}

Forrás (Source): Saját kutatás (Own research), 2013 
A vásárlás elutasításának lehetséges okai (Possible Reasons for the Rejection of Purchase)

$(\mathrm{N}=1038)$

\begin{tabular}{lc}
\hline \multicolumn{1}{c}{$\begin{array}{c}\text { Válaszlehetöségek } \\
\text { (Answers) }\end{array}$} & $\begin{array}{c}\text { Az ,igen” válaszok } \\
\text { megoszlása } \\
\text { (Distribution of } \\
\text { Answers „Yes”) (\%) }\end{array}$ \\
\hline $\begin{array}{l}\text { Emberre veszélyes alapanyagok használata } \\
\text { (Use of materials hazardous for humans) }\end{array}$ & 70,1 \\
\hline $\begin{array}{l}\text { Felhasznált alapanyagok kétes eredete (Use of materials with dubious origin) } \\
\text { Környezetszennyezés (alapanyagok, gyártástechnológia stb.) } \\
\text { (Pollution of environment (raw materials, manufacturing technology etc.)) }\end{array}$ & 55,6 \\
\hline Állatkísérletek alkalmazása (Use of animal experiments) & 48,4 \\
\hline $\begin{array}{l}\text { Természetkárosítás (élőhelyek, élővilág tönkretétele) } \\
\text { (Nature damage (habitats, wildlife destruction)) }\end{array}$ & 46,0 \\
\hline Gyerekmunka (Children's work) & 43,2 \\
\hline Adócsalás, adókerülés (Tax fraud, tax evasion) & 41,5 \\
\hline $\begin{array}{l}\text { Emberi jogok megsértése (ún. hátrányos megkülönböztetés) } \\
\text { (Human rights violations (discrimination)) }\end{array}$ & 22,7 \\
\hline $\begin{array}{l}\text { Versenyszabályok megsértése (tisztességtelen reklám, kartellezés) } \\
\text { (Infringement of competition rules (unfair advertising, cartel)) }\end{array}$ & 21,4 \\
\hline Feketemunka (Undeclared work) & 19,9 \\
\hline Rendszeres túlóráztatás (Regular overtime) & 17,7 \\
\hline Egyik sem (None of them) & 13,3 \\
\hline Forrás (Source): Saját kutatás (Own research), 2013 & 2,6 \\
\hline
\end{tabular}

3.2. A fenntartható vállalati tevékenységek figyelemmel kísérése alapján elküilöníthető fogyasztói csoportok - Consumer Groups Separated on the Basis of Monitoring Sustainable Business Activities

Kutatásunk során választ kerestünk arra a kérdésre, hogy a vállalatok fenntarthatóság érdekében tett erőfeszítéseinek megítélése, valamint az ehhez kapcsolódó információk követése alapján kimutathatók-e jellegzetes fogyasztói csoportok. A klaszterelemzés lefolytatásához K-means módszert alkalmaztunk, mely eredményeként négy jellegzetes csoport vált elkülöníthetővé egymástól. A klaszterek jellemzői alapján a vállalati szféra számára is lényeges szempontok merülnek fel, amelyeken keresztül a fenntartható fogyasztás előmozdíthatóvá válik, és ideális célcsoportok jelennek meg az élelmiszereket gyártó vállalatok számára.
A csoportokban megjelenő változóátlagok a csoportok között szignifikánsan különböznek egymástól. A csoportokat leginkább megkülönböztető jellemző a vállalatok fenntartható fejlődés érdekében tett erőfeszítéseinek fontossága ( $\mathrm{F}=887,9 ; \mathrm{p}=0,000)$ illetve az, hogy milyen gyakran olvassák el a napi fogyasztási cikkek csomagolásain található információkat erre vonatkozóan $(\mathrm{F}=678,5 ; \mathrm{p}=0,000) . \mathrm{Az}$, hogy egy fogyasztó mit tesz, ha egy rendszeresen vásárolt termék gyártójáról negatív hírekhez jut $(\mathrm{F}=307,0 ; \mathrm{p}=0,000)$ vagy nyomon szokta-e követni, hogy a rendszeresen vásárolt termékek gyártója mit tesz a fenntartható fejlődés érdekében $(\mathrm{F}=236,5 ; \mathrm{p}=0,000)$ kevésbé határozzák meg a klaszterek elkülönülését. A klaszterek szignifikáns eltérést mutatnak egymástól mind a négy jellemző alapján. Az egyes csoportok sajátosságainak részletes jellemzését az alábbiakban ismertetjük. 


\section{1. klaszter - passzív egészségtudatosak}

A klaszter a harmadik legnagyobb csoportot alkotja a mintán belül (27,4\%). A fenntartható fejlődés elősegítése érdekében tett személyes erőfeszítések kevéssé jellemzik, sem a rendszeresen vásárolt termékek gyártóinak nyomon követése. Kiemelkedik viszont a többi csoport közül a napi fogyasztási cikkek csomagolásairól származó információk és a fenntartható fejlődés érdekében tett vállalati lépések figyelemmel kísérésében. Jobb véleményük alakul ki egy vállalattal kapcsolatban a hátrányos helyzetűek támogatása, az egészségügy támogatása, a szegények támogatása, az elmaradott települések támogatása és a környezetkárosító tevékenység(ek) csökkentéséről szóló információk nyomán.

Bojkottokra való hajlandóságuk a legalacsonyabb, a rendszeresen vásárolt termékek gyártóiról szóló negatív hírek esetén kevésbé reagálnának érzékenyen, az átlagnál magasabb mértékben csak a felhasznált alapanyagok kétes eredete vagy az emberre veszélyes alapanyagok használata, amelyek esetén elutasítanák a további vásárlást.

\section{2. klaszter - pesszimisták}

A csoport aránya a teljes mintasokaságon belül (30,7\%), ezzel a második legnagyobb csoportot alkotja. A fenntartható fejlődés elősegítése érdekében tett személyes erőfeszítések átlagos szinten jellemzik őket, hasonlóképp a fenntartható fejlődés érdekében tett vállalati lépések figyelemmel kísérése. A napi fogyasztási cikkek csomagolásairól származó információkat magas arányban figyelik, a rendszeresen vásárolt termékek gyártóinak nyomon követése és a vásárlás elutasítása a rendszeresen vásárolt termék gyártójáról negatív hírek esetén nem jellemző a csoportra. Pozitív üzenet lehet számukra az elmaradott települések támogatása, a környezetvédelmi beruházások finanszírozása, a környezetkárosító tevékenység(ek) csökkentése, a sport támogatása és az oktatás támogatása.

A további vásárlás elutasítása negatív hírek esetén a gyermekmunka alkalmazása, a feketemunka, a környezetszennyezés, a természetkárosítás, az állatkísérletek, a felhasznált alapanyagok kétes eredete, az emberre veszélyes alapanyagok használata és az emberi jogok megsértése (ún. hátrányos megkülönböztetés) esetén átlagos, más jellemzók esetében elmarad a többi csoporttól.

\section{3. klaszter - passzív elfogadóak}

A csoport aránya 33,1\%, a legnagyobb a teljes mintasokaságon belül. Az, hogy személyesen minden tôlük telhetőt megtesznek a fenntartható fejlődés érdekében leginkább jellemzô rájuk. A napi fogyasztási cikkek csomagolásairól való információgyüjtés átlagos, viszont a fenntartható fejlődés érdekében tett vállalati lépések figyelemmel kísérése és a gyártóikkal kapcsolatos hírek nyomon követése egyaránt legalacsonyabb az összes csoport közül. A rendszeresen vásárolt termék gyártójáról szóló negatív hírek esetén legkevésbé elutasító ez a csoport.

Jobb véleményük alakul ki egy vállalattal kapcsolatban: az állatvédelem támogatása, az energiatakarékos megoldások alkalmazása, a megújuló erőforrások használata, a művészet támogatása és környezetvédelmi beruházások finanszírozása esetén. Azok a hírek, amelyeket követően elutasítanák a további vásárlást: a gyermekmunka, a feketemunka, a környezetszennyezés, a természetkárosítás, az állatkísérletek, a felhasznált alapanyagok kétes eredete, az emberre veszélyes alapanyagok használata, az emberi jogok megsértése (ún. hátrányos megkülönböztetés).

\section{4. klaszter - aktív városiak}

A klaszterben a megkérdezettek 8,8\%-a jelenik meg. Az, hogy személyesen minden tőlük telhetőt megtesznek a fenntarthatóság elérése érdekében, az átlagnál jobban jellemzi őket. Kiemelkedően foglalkoztatja ezt a csoportot, hogy a vállalatok mit tesznek a fenntartható fejlődés érdekében és a rendszeresen vásárolt termék gyártójáról szóló negatív hírek esetén leginkább elutasítóak. A rendszeresen vásárolt termékek gyártóinak nyomon követésében is átlagon felüli válaszokat adtak. A napi fogyasztási cikkek csomagolásain megtalálható információkat azonban kevésbé figyelik, mint más klaszterek tagjai.

Jobb véleményük alakul ki hátrányos helyzetűek támogatása, környezetkárosító tevékenység(ek) csökkentése, környezetvédelmi beruházások finanszírozása, szegények 
támogatása, természetes élőhelyek megóvása esetén. Elutasítanák a további vásárlást, ha adócsalásról, rendszeres túlóráztatásról, feketemunkáról, a felhasznált alapanyagok kétes eredetéről, emberre veszélyes alapanyagok használatáról hallanának.

A fogyasztói szegmensek élelmiszerek vásárlásával összefüggő jellegzetességeit a
3. táblázat mutatja be, amely szerint szignifikáns eltérés mutatható ki a felsorolt jellemzők esetében. Jól látszik, hogy a hazai fogyasztók számára a klasszikus értékek (az élelmiszerek ára, íze és frissessége, a beszerzés költségei) fontosabbnak bizonyulnak, mint például az élelmiszerekkel kapcsolatos egészségkockázatok vagy az élelmiszerek származási helye.

3. TÁBLÁZZAT

A fogyasztói szegmensek élelmiszer-vásárlással összefüggó jellemzői

TABLE 3 (Characteristics of the Consumer Segments) (N=1038)

\begin{tabular}{|c|c|c|c|c|c|c|c|}
\hline \multirow{2}{*}{$\begin{array}{l}\text { Válaszlehetôségek } \\
\text { (Answers) }\end{array}$} & \multicolumn{4}{|c|}{$\begin{array}{c}\text { A fogyasztói szegmensek } \\
\text { jellemzöi (Characteristics } \\
\text { of Consumer Segments) }\end{array}$} & \multicolumn{3}{|c|}{$\begin{array}{c}\text { A minta jellemzői } \\
\text { (Characteristics of the } \\
\text { Sample) }\end{array}$} \\
\hline & $\mathbf{1}$ & 2 & 3 & 4 & $\mathbf{F}$ & $\begin{array}{l}\text { Szign. } \\
\text { (Sig.) }\end{array}$ & $\begin{array}{l}\text { Mintaátlag } \\
\text { (Sample } \\
\text { Mean) }\end{array}$ \\
\hline Az élelmiszerek ára (The price of food) & 4,28 & 3,89 & 4,74 & 4,84 & 94,60 & 0,000 & 4,55 \\
\hline $\begin{array}{l}\text { A beszerzés költségei (The cost of } \\
\text { acquisition) }\end{array}$ & 4,17 & 3,72 & 4,36 & 4,65 & 36,98 & 0,000 & 4,34 \\
\hline $\begin{array}{l}\text { Az élelmiszerek külső tulajdonságai } \\
\text { (méret, szín, alak, forma) (External } \\
\text { characteristics (size, color, shape, } \\
\text { form) offood) }\end{array}$ & 3,77 & 3,52 & 3,72 & 4,22 & 26,16 & 0,000 & 3,90 \\
\hline $\begin{array}{l}\text { Az élelmiszer belső tulajdonságai } \\
\text { (pl. tápanyag, vitamin, energiatar- } \\
\text { talom (The inherent characteristics } \\
\text { of the food (e.g. nutrients, vitamins, } \\
\text { energy)) }\end{array}$ & 3,95 & 3,56 & 4,29 & 4,67 & 79,50 & 0,000 & 4,26 \\
\hline $\begin{array}{l}\text { Az élelmiszer íze és frissessége } \\
\text { (The taste and freshness of food) }\end{array}$ & 4,18 & 3,76 & 4,63 & 4,86 & 129,55 & 0,000 & 4,49 \\
\hline $\begin{array}{l}\text { Az egészséges táplálkozás követelmé- } \\
\text { nyeinek való megfelelés (Compliance } \\
\text { with the requirements of a healthy } \\
\text { diet) }\end{array}$ & 3,80 & 3,43 & 4,08 & 4,51 & 59,15 & 0,000 & 4,09 \\
\hline $\begin{array}{l}\text { Az étkezési szokásaimhoz való ragasz- } \\
\text { kodás (Insistence on eating habits) }\end{array}$ & 3,86 & 3,50 & 3,98 & 4,27 & 29,49 & 0,000 & 4,00 \\
\hline $\begin{array}{l}\text { Az élelmiszer kínálat szerkezete és } \\
\text { választéka (The structure of supply } \\
\text { and choice offood) }\end{array}$ & 3,89 & 3,54 & 4,03 & 4,58 & 79,73 & 0,000 & 4,14 \\
\hline $\begin{array}{l}\text { Az élelmiszerek vonzó csomagolása } \\
\text { (The attractive food packaging) }\end{array}$ & 3,65 & 3,33 & 3,27 & 3,80 & 16,25 & o,ooo & 3,58 \\
\hline $\begin{array}{l}\text { Az élelmiszerek származási helye (or- } \\
\text { szág-eredet, helyi eredet) (The place } \\
\text { of origin of foods (country of origin, } \\
\text { local origin)) }\end{array}$ & 3,83 & 3,48 & 3,87 & 4,37 & 35,94 & 0,000 & 4,00 \\
\hline $\begin{array}{l}\text { Az élelmiszerekkel kapcsolatos } \\
\text { egészségkockázatok (The health risks } \\
\text { associated with food) }\end{array}$ & 4,12 & 3,55 & 4,20 & 4,69 & 88,51 & 0,000 & 4,28 \\
\hline
\end{tabular}


KovÁcs, I. - LEHOTA, J. - KOMÁROMI, N.

4. TÁBLÁZAT

A fogyasztói klaszterek szocio-demográfiai jellemzői, \%

TABLE 4

(Socio-demographic Variables of Consumer Clusters, \%)

$(\mathrm{N}=1038)$

\begin{tabular}{|c|c|c|c|c|c|c|}
\hline \multirow{2}{*}{$\begin{array}{c}\text { Változó } \\
\text { (Variables) }\end{array}$} & \multirow{2}{*}{$\begin{array}{c}\text { Válaszlehetôségek } \\
\text { (Answers) }\end{array}$} & \multicolumn{4}{|c|}{$\begin{array}{l}\text { Fogyasztói klaszterek } \\
\text { (Consumer Clusters) }\end{array}$} & \multirow{2}{*}{$\begin{array}{l}\text { Szig. } \\
\text { (Sig.) }\end{array}$} \\
\hline & & $\mathbf{1}$ & 2 & 3 & 4 & \\
\hline \multirow{4}{*}{$\begin{array}{l}\text { Településtípus } \\
\text { (Settlement) }\end{array}$} & Budapest & 9,5 & 15,2 & 18,0 & 29,4 & \multirow{4}{*}{0,000} \\
\hline & Nagyváros (Big town) & 21,4 & 20,4 & 15,5 & 20,9 & \\
\hline & Kisváros (Small town) & 47,6 & 29,2 & 32,6 & 14,7 & \\
\hline & Falu (Village) & 21,4 & 35,3 & 33,9 & 35,1 & \\
\hline \multirow{2}{*}{$\begin{array}{l}18 \text { év alatti gyermek a } \\
\text { háztartásban (Presence of } \\
\text { children under } 18 \text { years in } \\
\text { household) }\end{array}$} & Igen (Yes) & 31,0 & 22,1 & 16,3 & 19,0 & \multirow{2}{*}{0,029} \\
\hline & $\operatorname{Nem}(\mathrm{No})$ & 69,0 & 77,9 & 83,7 & 81,0 & \\
\hline \multirow{9}{*}{$\begin{array}{l}\text { Foglalkozás } \\
\text { (Occupation) }\end{array}$} & $\begin{array}{l}\text { Független/Önálló vállalkozó } \\
\text { (Independent/Self employed) }\end{array}$ & 1,2 & 2,5 & 2,9 & 2,4 & \multirow{9}{*}{0,017} \\
\hline & $\begin{array}{l}\text { Vezető/Szakértő } \\
\text { (Managerial/Professional) }\end{array}$ & 2,4 & 2,5 & 2,1 & 4,7 & \\
\hline & $\begin{array}{l}\text { Szellemi munkás } \\
\text { (White collar worker) }\end{array}$ & 20,2 & 19,3 & 18,8 & 30,3 & \\
\hline & $\begin{array}{l}\text { Fizikai munkás } \\
\text { (Blue collar worker) }\end{array}$ & 15,5 & 17,4 & 15,1 & 14,2 & \\
\hline & Nyugdíjas (Retired) & 26,2 & 29,0 & 33,9 & 22,7 & \\
\hline & Munkanélküli (Unemployed) & 14,3 & 9,4 & 11,3 & 3,3 & \\
\hline & Tanuló (Student) & 6,0 & 8,6 & 9,2 & 11,4 & \\
\hline & Háziasszony (Housewife) & 4,8 & 4,4 & 4,2 & 3,8 & \\
\hline & $\mathrm{NT} / \mathrm{NV}(D K / N A)$ & 9,5 & 6,9 & 2,5 & 7,1 & \\
\hline \multirow{6}{*}{$\begin{array}{l}\text { Háztartás mérete } \\
\text { (Size of household) }\end{array}$} & 1 fö (1 person) & 28,9 & 30,6 & 35,7 & 35,1 & \multirow{6}{*}{0,000} \\
\hline & 2 fö (2 persons) & 32,5 & 29,8 & 35,7 & 39,8 & \\
\hline & 3 fö (3 persons) & 9,6 & 22,6 & 16,4 & 9,5 & \\
\hline & 4 fö (4 persons) & 20,5 & 11,8 & 7,6 & 8,5 & \\
\hline & 5 fö (5 persons) & 8,4 & 4,1 & 3,4 & 4,7 & \\
\hline & 6-nál több fő (6+ persons) & 0,0 & 1,1 & 1,3 & 2,4 & \\
\hline
\end{tabular}

Forrás (Source): Saját kutatás (Own research), 2013

A vizsgált háttérváltozók: a lakóhely településtípusa ( $\mathrm{p}=0,000), 18$ év alatti gyermek a háztartásban $(\mathrm{p}=0,029)$, foglalkozás $(\mathrm{p}=0,017)$, valamint a háztartás mérete $(\mathrm{p}=0,000)$ alapján szignifikáns különbség mutatható ki a klaszterek között (4. táblázat).

Összefoglalva kijelenthető, hogy a passzív egészségtudatosak és az aktív városiak ideális célcsoportjai lehetnek az élelmiszereket gyártó vállalatoknak. A passzív egészségtudatosak tudatosan döntenek, ami egyrészt információ- kereső magatartásukban, másrészt abban a jellemzőben is megnyilvánul, hogy érdekli őket, hogy egy gyártó mennyit tesz a fenntartható fejlődés érdekében. Az aktív városiak kevésbé bíznak abban, hogy vásárlásaikkal a fenntarthatóság érdekében tudnak tenni, viszont információkereső jellemzőjük kiemelkedő és többségben utasítanák el a további vásárlásokat a vállalatokról szóló negatív hírek alapján. 


\section{KöVETKEZTETÉSEK - CONCLUSIONS}

Eredményeink szerint a magyar fogyasztók élelmiszer-fogyasztási szokásai még mindig a tradicionális elvet követik, a klasszikus értékek (az élelmiszerek ára, íze és frissessége, a beszerzés költségei) fontosabbnak bizonyulnak, mint például az élelmiszerekkel kapcsolatos egészségkockázatok vagy az élelmiszerek származási helye. A válaszadók 39\%-a személyesen is megtesz minden tőle telhetőt a fenntartható fejlődés érdekében, ezen belül pedig 12\%-uk a környezetét is igyekszik befolyásolni és hasonló hozzáállásra buzdítani. Csupán a fogyasztók $18,1 \%$-a nem hisz abban, hogy bármit is tudna tenni a fenntartható fejlődés érdekében és ezért nem is foglalkozik vele. A fenntarthatóság érdekében tett erőfeszítések sorrendje alapján leginkább az energiatakarékosságra való törekvés több formája, valamint az újrahasznosítás terjedt el, és emellett jelenik meg a helyi előállítású / termesztésű termékek előnyben részesítése, a környezetbarát termékek vásárlása.

A vállalatok fenntartható fejlődés érdekében tett erőfeszítéseit a hazai fogyasztók közel harmada tartja fontosnak vagy semlegesnek, 38\%-uk pedig kevésbé vagy egyáltalán nem törődik azzal, hogy a gyártók tesznek-e a fenntartható fejlődés érdekében. A környezetkárosító tevékenység(ek) csökkentése, az egészségügy támogatása, a hátrányos helyzetűek támogatása, a környezetvédelmi beruházások finanszírozása, és az energiatakarékos megoldások alkalmazása azok a kiemelkedő vállalati lépések, amelyek pozitív fogyasztói megítélést vonzanak. A rendszeresen vásárolt termék gyártójáról szóló negatív hírek után a fogyasztók kisebb hányada változtatna korábbi vásárlási szokásain. A leginkább elutasított vállalati tevékenységek az emberre veszélyes alapanyagok használata, a felhasznált alapanyagok kétes eredete és a környezetszennyezés. Ezen eredmények alapján a hazai fogyasztók nyitottak a társadalmilag felelős fogyasztás egyes megjelenési formáinak figyelembe vételére.

A fenntartható vállalati tevékenységek figyelemmel kísérése alapján négy jellegzetes csoportot különítettünk el, amelyek közül a passzív egészségtudatosak és az aktív városiak ideális célcsoportjai lehetnek a társadalmilag tudatos fogyasztókat elérni kívánó élelmiszereket gyártó vállalatoknak. A csoportok között eltérések mutatkoznak abban, hogy melyek azok a vállalati lépések, amelyek alapján a fogyasztónak jobb véleménye alakul ki egy vállalattal kapcsolatban, illetve melyeket utasítanak el. Eredményeink szerint a vállalatok fenntarthatósághoz való hozzájárulásának figyelembe vétele több fogyasztói csoport jellemzői között is megjelenik, amely a vállalatok számára a fenntartható fogyasztás elősegítéséhez való hozzájárulás lehetőségét adja, a fenntarthatóság iránt elkötelezett fogyasztók új típusú szükségleteinek felismerésén és kielégítésén keresztül.

\section{5. ÖSSZEFOGLALÁs - SUMMARY}

Kutatómunkánk során átfogó piackutatást végeztünk a vállalatok fenntartható fejlődés érdekében tett lépéseinek fogyasztói megítéléséről. Célunk a hazai lakosság fenntartható fogyasztás előmozdítását segítő vállalati kezdeményezésekkel összefüggő ismereteinek, attitűdjeinek és preferenciáinak részletes feltárása volt. Eredményeink szerint a fogyasztói igények között, a fenntarthatósághoz való hozzájárulás iránti elkötelezettség és a termelők fenntartható múködésének figyelembe vétele, valamint az etikus terméktulajdonságok iránti igények erősödése is megjelenik. A kutatásunkban bemutatott fogyasztói csoportokban a fenntartható fogyasztással kapcsolatos pozitív fogyasztói attitűdök és a felelős vállalati magatartás fogyasztói döntésekben való megjelenése igazolhatók. Az eredményekből levonható következtetések irányt mutathatnak az élelmiszeriparban tevékenykedő vállalatok számára a fenntarthatóság iránt elkötelezett fogyasztói csoportok jellemzőinek megismeréséhez, amelyben megjelenik a vállalatok fenntarthatóság érdekében tett erőfeszítéseinek megítélése, valamint az ehhez kapcsolódó információk követése. 
IRODALOMJEGYZÉK - REFERENCES

Anderson, W. T. JR. - Cunningham W. H.: The Socially Conscious Consumer. In: Journal of Marketing. 1972. 36 (1) 23-31.

Berkowitz, L. - Lutterman K. G.: The Traditional Socially Responsible Personality. In: Public Opinion Quarterly. 1968. 32 (2) 169-185.

Cooper-Martin, E. - Holbrook M. B.: Ethical Consumption Experiences and Ethical Space. In: Advances in Consumer Research. 1993. 20 (1) 113-118.

Crane, A.: Unpacking the ethical product. In: Journal of Business Ethics. 2001. 30 (4) 361-373.

François-Lecompte, A. - Roberts, J. A.: Developing a measure of socially responsible consumption in France. In: Marketing Management Journal. 2006. 16 (2) 50-66.

Gulyás E.: Az etikus fogyasztás értelmezései. In: Szociológiai Szemle. 2008. 19 (1) 106127.

Kovács I.: A társadalmilag felelős fogyasztói magatartás jellemzőinek vizsgálata. Doktori (PhD) értekezés. Szent István Egyetem, Gazdálkodás- és Szervezéstudományi Doktori Iskola, Gödöllő, 2015.

Lehota J. - Horváth Á. - Rácz G.: A potenciális LOHAS fogyasztók megjelenése Magyarországon. In: Marketing és Menedzsment. 2013. 47 (4) 36-53.

NBS: How far to go? Understanding the marketing effects and limits of corporate social responsibility? 2010. URL: http://nbs.net/wp-content/uploads/ RI-Understanding-the-marketingeffects-and-limits-of-corporate-socialresponsibility.pdf (Letöltés dátuma: 2015. okt. 5.)
Neilson, L. A.: Boycott or buycott? Understanding political consumerism. In: Journal of Consumer Behaviour. 2010. 9 (3) 214-227.

Nielsen: Társadalmi felelősségvállalás és fogyasztói döntés. 2014. URL: http:// hu.nielsen.com/site/20140619.shtml (Letöltés dátuma: 2014. aug. 2.)

Smith, C. N.: Bounded goodness: marketing implications of Drucker on corporate responsibility. In: Journal of the Academy of Marketing Science. 2008. 37 (1) 73-84.

Szakály Z. - Pető K. - Popp J. - Jasák H.: A LOHAS szegmens mérete és jellemzői Magyarországon. In: Táplálkozásmarketing. 2015. 2 (1) 11-30.

TVE: Etikus fogyasztói attitüdök Magyarországon. 2005. URL: http:// tudatosvasarlo.hu/sites/default/files/ etfogyattitud2.1.pdf (Letöltés dátuma: 2013. dec. 16.)

TVE: A magyar felnőtt lakosság fenntartható fogyasztással kapcsolatos tudása és cselekvési attitűdjei. Tudatos Vásárlók Egyesülete, Budapest, 2010.

Webb, D. J. - Mohr, L. A. - Harris, K. E.: A re-examination of socially responsible consumption and its measurement. In: Journal of Business Research. 2008. 61 (2) 91-98.

Webster, F. E.: Determining the Characteristics of the Socially Conscious Consumer. In: Journal of Consumer Research. 1975. 2 (3) 188-196. 